The Internet and Formations of Iranian American-ness Next Generation Diaspora

Donya Alinejad

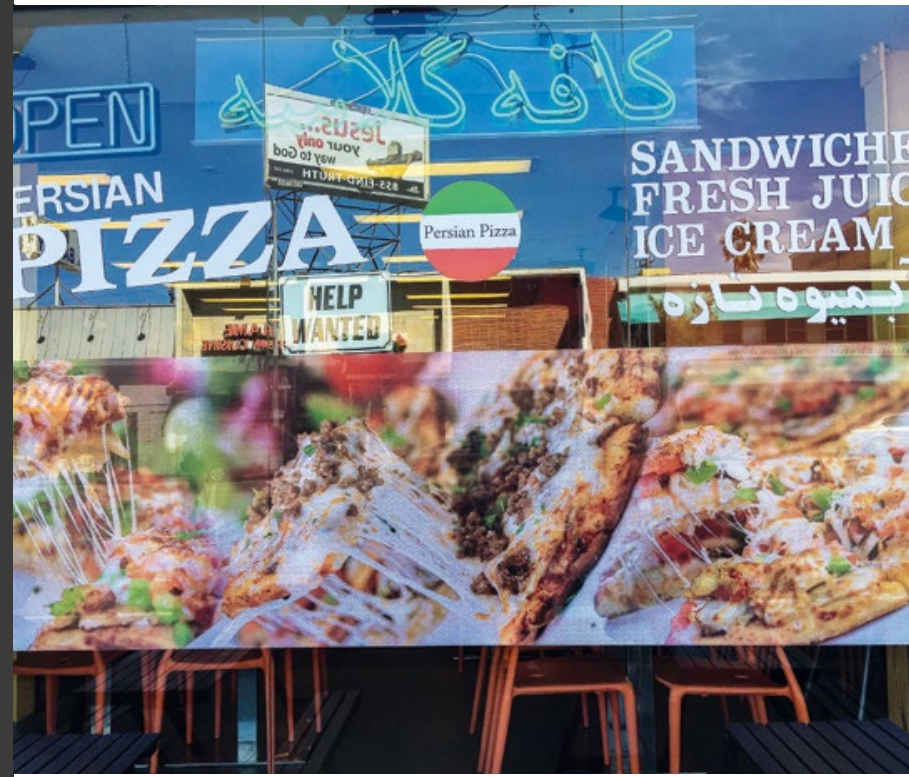

105 likes

view all 25 comments

hushi9 Back 2 the hood \#Vestvood

raminehaji Number VON!!!!!!

hushi9 Patogh Parvin khanoum Pattyarah

@raminehaji

larkoshi very tazeh
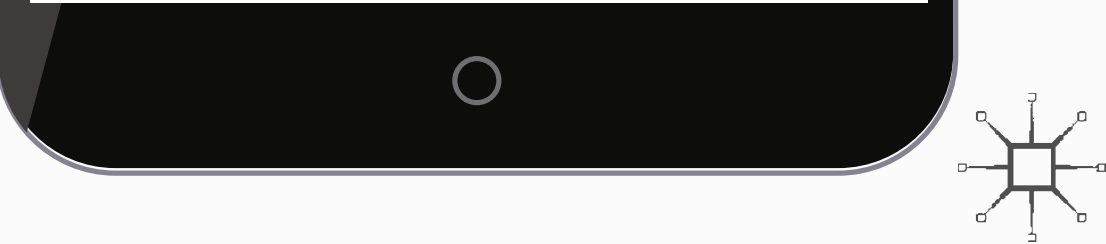
The Internet and Formations of Iranian American-ness 
Donya Alinejad

\section{The Internet and}

Formations of Iranian American-ness

Next Generation Diaspora 
Donya Alinejad

Utrecht University

Utrecht, The Netherlands

ISBN 978-3-319-47625-4

ISBN 978-3-319-47626-1 (eBook)

DOI 10.1007/978-3-319-47626-1

Library of Congress Control Number: 2017930309

(C) The Editor(s) (if applicable) and The Author(s) 2017

This work is subject to copyright. All rights are solely and exclusively licensed by the Publisher, whether the whole or part of the material is concerned, specifically the rights of translation, reprinting, reuse of illustrations, recitation, broadcasting, reproduction on microfilms or in any other physical way, and transmission or information storage and retrieval, electronic adaptation, computer software, or by similar or dissimilar methodology now known or hereafter developed.

The use of general descriptive names, registered names, trademarks, service marks, etc. in this publication does not imply, even in the absence of a specific statement, that such names are exempt from the relevant protective laws and regulations and therefore free for general use. The publisher, the authors and the editors are safe to assume that the advice and information in this book are believed to be true and accurate at the date of publication. Neither the publisher nor the authors or the editors give a warranty, express or implied, with respect to the material contained herein or for any errors or omissions that may have been made. The publisher remains neutral with regard to jurisdictional claims in published maps and institutional affiliations.

Cover illustration: Hushidar Mortezaie

Printed on acid-free paper

This Palgrave Macmillan imprint is published by Springer Nature The registered company is Springer International Publishing AG

The registered company address is: Gewerbestrasse 11, 6330 Cham, Switzerland 
Dedicated to my mother, Sima Asvadi 


\section{ACKNOWLEDGMents}

I would like to express my thanks to the Netherlands Organization for Scientific Research (NWO), Prins Bernhard Cultuurfonds, the Department of the Social and Cultural Anthropology, and the Faculty of Social Science at the VU University for providing the research and travel grants that made the research for this book possible. My gratitude also goes out to the members of my Ph.D. reading and defense committee: Mehdi Bozorgmehr, Annelies Moors, Jeroen de Kloet, Lenie Brouwer, and Susan Legen, who examined the dissertation that formed the basis of this book. My Ph.D. supervisors Birgit Meyer and Halleh Ghorashi were instrumental in this process and I thank them both for their motivation and guidance. Many thanks also to my family who helped me along the way, in particular to all the Asvadi sisters for the unconditional support and endless inspiration. To the people who let me into their lives and shared bits and pieces of their space, thoughts, food, family, and selves with me over the time I got to know them in Los Angeles, you have my eternal thanks. Amy Malek, Arash Saedinia, Arash Davari, Sepideh Saremi, Beeta Baghoolizadeh, Shiva Goudarzi, Pouya Alimagham, Neda Maghbouleh, Nina Farnia, Pouneh Behin and others, I consider you my peers and experts and I thank you for caring so fiercely for your communities and causes. My gratitude also goes out to Betty Blair for answering my questions, to the Ph.D. Club of the former Organizational Sciences Department for the discussions, to the ever-memorable Mario Rutten for teaching me most of what I knew about actually doing ethnography upon entering the field, to the UvA Methods Clinic run by the inspiring and late Gerd Baumann, and to the staff of the Department of Social and 
Cultural Anthropology for the collegiality. I feel lucky to now be part of the "Dream Team" at Utrecht University, including Laura Candidatu, Claudia Minchilli, and Melis Mevsimler. I am indebted in particular to Koen Leurs and Sandra Ponzanesi for giving me fresh ways to look at my work and the opportunity to continue it in the ERC project, Digital Crossings in Europe: Gender, Diaspora and Belonging. Domitilla Olivieri, thank you for everything. Special thanks are in order for my friends and comrades who have been there throughout-Marten Boekelo, Ama van Dantzig, Hikaru Toda, Maria Makayonok, Dinu Abdella, Jelle Bruinsma, Matthias van Rossum, Melanie Eijberts, Saskia Baas, Brett Kosterman Zoller, Scott Dalby, Catherine Black, Miriyam Aouragh, and other friends from the International Socialists in Amsterdam-the experience could never have been the same without you. To the corageous women and men who rose up in Iran, the sparks from your sacrifices burn on to this day and beyond. Finally, thank you to the Verontuste VUers and the Maagdenhuis occupiers for keeping our very souls alive. May we live to celebrate great victories together. 


\section{Contents}

1 Introduction 1

2 Theories of Migrancy and Media 31

3 Memory $\quad 59$

4 Race 101

5 The Green Movement 153

6 Conclusion $\quad 185$

$\begin{array}{ll}\text { Index } & 195\end{array}$ 


\section{Introduction}

"Not to toot my own horn or anything," Sepideh said, "but I was doing what Nokteez did in the UK years before them." Sepideh and I were sitting together at the desk in the bedroom of her Santa Monica rental, both facing her wide, sleek computer screen as she clicked between the various sites she was showing me. Nokteez.com ${ }^{1}$ was a London-based website that described itself as a project that "collects and shares slices of Contemporary Iranian culture, in the fields of art, music, design, theatre and film." To Sepideh, Nokteez was exemplary of the emergence of blogs and websites written in English by Iranian migrants outside Iran and focusing on Iranian cultural production. Sitting at her desk, she navigated swiftly between some of the sites and blogs she followed, as she told me about her work on a blog called Parsarts, which she had started up some years prior. With its byline, "Iranian Diaspora Life/Culture/ Identity," Sepideh had begun Parsarts to highlight "Iranian life and culture abroad." 2 The striking thing about Parisa's blog was how rooted it was in her own particular way of being Iranian.

Something of an early adopter of blogging platforms, Sepideh had worked in web content editing, and soon after I met her in California in 2008, she began working for an online startup media company in Santa Monica. Her work for the blog had helped her gain and deepen contact with a range of others equally interested in questions of how Iranian-ness was taking shape outside Iran. And she had met, interviewed, and written about Iranian diasporic filmmakers, authors, and artists. Her friends described her as

D. Alinejad, The Internet and Formations of Iranian American-ness, DOI 10.1007/978-3-319-47626-1_1 
being especially active at the intersection of emerging digital technologies and Iranian diasporic culture, and she had been blogging about the topic since 2002. Embedded within a variety of social relationships and inspired by her personal reflections on her own Iranian and American-ness, Sepideh's blog was part of her ongoing process of figuring out how to relate to her own Iranian cultural background from a very situated experience of everyday life in Los Angeles (LA), California.

But Sepideh's world was a very different one than I had envisioned when I first set out in 2008 to conduct field research in LA about Iranian diaspora bloggers. Having been intrigued by the Iranian blogging phenomenon that rose significantly in the early 2000s, I was drawn to the unique border-crossing potential of blogs, for helping diaspora bloggers and readers participate from a distance in the predominantly Iran-based, Farsi language blog scene known as Weblogistan/"Veblogestan" (AmirEbrahimi 2004; Doostdar 2004; Hendelman-Baavur 2007; Alinejad 2011; Shakhsari 2011). ${ }^{3}$ I was impressed by stories about the political potential of easy-to-use blogging applications and the brave acts of political dissidents in the Islamic Republic, including those who had gained large audiences internationally and those who eventually had to flee overseas to pursue their web publishing (and other) activities. ${ }^{4}$

I had previously conducted "virtual ethnographic" (Hine 2000) research on English language political diaspora blogs by Iranians, including conducting interviews with some of the key international figures in this political scene (Alinejad 2011). So in an effort to elaborate on that interest, I went to LA, the city known for being home to the highest number of Iranians outside Iran, with the intention of finding out more about the lives of those who were engaging with this Iranian blog scene from a distance. Sepideh was one of the people I met early on, and I asked her how involved she was with this online sphere and the diaspora-bloggerdissident phenomenon. Her response was one I came to hear echoed time and again by others in the course of my time in LA, and in particular from the children of Iranian parents who had grown up in the USA: "The time it takes for me to read those [blogs] is simply too long. ${ }^{5}$ And the context they are writing from doesn't speak to me. Their experience is not mine." The response confronted me at once with a problem and an insight.

My initial interest had been mostly shaped by international media coverage of Iranian blogs, and my starting point was informed by previous research I had largely conducted online, about blogs written from dispersed locations. Contextualizing diaspora blogging within offline life 
came with the challenge of locating where it was lived, and it also meant that the investigation would necessarily be shaped by that context. And so, it was. Several of those I met, interviewed, and befriended in LA could have fit the profile of the diaspora-blogger-dissident to various degrees. But getting to know them confirmed what Sepideh's response had also indicated: Iranian diaspora bloggers were much more diverse than I had imagined, and blog users who were politically engaged with developments in Iran were largely disconnected, in both their online and offline practices, from second-generation bloggers like Sepideh. Hers was a mode of Iranian diasporic internet use I likely would not have found out about without being in LA, and by conducting ethnographic field research in this context for over a year, I witnessed intensifications of engagement with diasporic Iranian cultural production by the children of Iranian migrants in this city. Sepideh's blog foreshadowed a number of young people's efforts toward starting up English language, web-based projects focusing on Iranian culture, history, and arts, and scholarly writing in ways that appealed to them.

The striking thing about these projects was that they were curated in line with the author(s)'s vision and were started by a generation of Iranians who had grown up outside Iran. This not only set them apart from diaspora bloggers with political ties to Iran but also set them apart from prominent Iranian diaspora websites-like Iranian.com, which was predominantly run for and by the first generation of Iranian migrants in the USA - which were more intended as broad, interactive discussion platforms. Instead, sites like Ajam Media Collective, Btaarof, Jigaram.com, and Yaddashts, predominantly produced by the US-based second generation, are small-scale projects, each with their own scope and particular emphasis. Non-existent just a few years prior, these projects sprouted up independently, and signaled a possible shift in how Iranian American-ness was being given meaning by a new generation who had their own experiences and ways of using digital media.

This made me interested to find out more about how this particular moment might indicate a change in what Iranian American-ness meant, and how a new generation of young people and their next-generation applications and devices might be developing a new, mediated engagement with the notion of diaspora. As an anthropologist I knew that, like all diaspora communities, the Iranian diaspora had never been a static entity but was always a dynamic social formation. And I situate my work with relation to research on Iranian diaspora populations in LA that has investigated the changing modes of belonging and identity formation over time (Naficy 1993; Sullivan 2001; Ghorashi 2002). And yet, with the 
current high pace of technological advancement, it is overdue that scholarly work on Iranian diaspora also begins to understand the role of digital media. Furthermore, there is a demographic and historical particularity to this moment in which a new generation of Iranian Americans is entering adulthood in a post-9/11 America, still engaged in the (expanding) War on Terror in a variety of sometimes unpredictable ways. This adds a degree of urgency to the need to trace how the current use of communications technologies is implicated within mediated local, transnational, and translocal processes of self and other formation.

This book tells a situated story of internet use by a particular part of the Iranian migrant population: second-generation internet users living in LA. It is a story that diverges from my initial intention to focus on the diasporic-blogger-dissidents, whose long distance politics tends to dominate international news headlines and Western imaginaries about Iranians and the internet. It also diverges from the story of their parent's generation who mostly migrated to the USA in the 1970s and 1980s, and who are typically drawn to different kinds of websites and media practices. This book seeks to investigate how digital media practices are part of the cultural practices of becoming Iranian American for this generation. In the remainder of this chapter, I introduce the field site, outline my fieldwork practice, and define the main research question that this book seeks to address. The situated approach I took to conducting this research meant studying people's usage practices in conjunction with the broader social and cultural context within which they take shape, including the broader diasporic media context. And in the case of the LA-based Iranian community, exile media production was an important part of this.

\section{Media Research Across Generations: From Exile TELEVISION TO INTERNET}

The Iranian media environment in LA has been suggested by Sreberny to be the most culturally rich in the Iranian diaspora (Sreberny 2001). In the context of my fieldwork, this was recognizable in the elaborate Persian language media production, which includes many print publications, radio stations, satellite television productions, and local cable broadcasts. A significant part of this industry is exile media production, which features both in the scholarship on Iranian diaspora and as a presence in the city's mediascape. Indeed, the significantly sized Iranian American population owes its presence to a considerable wave of exile migration around the 1980s. 
Tens of thousands of Iranians have been in LA since the first wave of migration to the USA in the 1960s through the early 1970s (Ghorashi and Boersma 2009). This was a period during which USA-Iran relations were relatively amicable, and LA and Tehran became sister cities. However, the reasons for migration changed from the often-temporary student migration to more extended or permanent exile and political refuge due to the Islamic Revolution of 1979. The latter led to a much more intense, second wave of emigration from Iran. ${ }^{6}$ The third wave is thought to have been set in motion since 1984 (Jalali 2005) and can be attributed in part to the consequences of the Iran-Iraq war of 1980-1988.

In-depth accounts of migrational trends to the USA have been covered in other research (Bozorgmehr 1997; Modarres 1998; Ghorashi 2002; Mobasher 2006) and will not be recapitulated in full here. Emigration from Iran since the 2009 uprising and the crackdown on student protesters and other activists signal another, much more recent wave that has been less researched as yet. The question that these dynamics raise is whether exile remains a useful concept with which to understand Iranian migration. This question becomes all the more pressing because increasingly diverse motivations and experiences underlie recent emigration from Iran, leading to a wider variety of migration narratives than the notion of exile can encompass.

Naficy's The Making of Exile Cultures: Iranian Television in Los Angeles (Naficy 1993) is a seminal conceptualization of exile media. Naficy's theorization sees the state of liminality in which Iranian exiles find themselves as a stage that at once connects them to the lost homeland while also encouraging adaptation to commercial values in American society through exile television production. His work can be placed within a body of qualitative research on Iranian migration to LA that addresses both the traumas of dramatic transformations caused by dispersion and displacement, and the possibilities and advantages of mobility. This work ${ }^{7}$ has tended to extend the application of exile as a conceptual frame for understanding the lives of Iranian Americans in LA to include adaptive and agentive social and cultural engagement by migrants. Recent research has also pointed to the usefulness of the exile framework in explaining continuities between the first and second generation. For instance, Maghbouleh situates the Persian language music industry-essentially an industry transported from Iran to LA after the Islamic revolution-within exilic modes of cultural production. She argues that these modes also generate second-generation claims to homeland and the appropriation of collective narratives of loss and 
pain, experienced vicariously by the younger generation through a shared interest in Persian music (Maghbouleh 2010).

In addition, Malek's essay on contemporary (literary) cultural production in the Iranian diaspora invokes the productive elements of Naficy's conceptualization of exile to argue that this allows contemporary Iranian cultural producers in the diaspora to occupy an "in-between" positioning as part of creating a "third space" in the vein of Homi Bhabha's notion (Malek 2006). The persistence and adaptation of the exile frame in understanding contemporary diasporic practices is interesting, and its relevance can perhaps be explained by the lasting fissures between Iran and USA state powers. That is, a lack of open, diplomatic relations between the two nation-state regimes means relatively more restrictions on movement for citizens. The Iranian state's repression of the 2009 Green uprising also speaks to the sustained and systematic legal and political persecution of dissidents. Under these circumstances, the sustained pertinence of exile as a way to understand experiences of Iranian migration makes sense.

It may mean that the children of Iranian migrants share more in common with those of Cuban immigrants ${ }^{8}$ than their Haitian equivalents who have been discussed as constituting a single "transnational generation" across borders due to ease of travel (Glick Schiller and Fouron 2001).9 Opportunities for return travel among the second generation of Iranians hinge on birth certificates, passports, parents' political background and circumstances of migration, severed social ties, family trauma, and fear of detention, on top of the usual financial and time considerations. Such travel is, therefore, neither a given nor fluid part of life for many of them, as (sometimes nebulous, sometimes clear-cut) obstacles mark the flows of their transmigrancy. ${ }^{10}$

Mason's work on Palestinian migrants shows how the second generation also engage with experiences of exile, and demonstrates that the role of transnational media such as books, songs, and poetry, as well as blogs and email, are particularly formative for the second generation's "virtual' relationship with the homeland" (Mason 2007). This work shows how issues of exile persist in specific ways in the second generation's media use, and make it relevant to understand what role internet technologies play under circumstances where transnational mobility is impeded for the diaspora (Aouragh 2011). Without overlooking the contemporary traces of exile, my intention in this book is to assess how applicable the frame of exile is to the Iranian American second generation's lived experiences and media practices. 
Anthropological work focusing specifically on the second generation of Iranian migrants is sparse. However, Sreberny (2000), McAuliffe (2007), and Maghbouleh (2012) present rich ethnographic accounts of the Iranian second generation in the West from the disciplines of media studies, human geography, and sociology, respectively. They reveal the nuances of diversity that come with the identifications that cross cut Iranian-ness (e.g. ethnic and religious). This attention to diversity is supported by Bozorgmehr's "internal ethnicity" notion, which also draws attention to axes of differentiation within the Iranian population in the USA (Bozorgmehr 1997). ${ }^{11}$ The work on the Iranian second generation also reflects less attention for media production dominated by middleaged Iranian men of the first generation, which, as Sreberny notes (2000), signals possibilities for greater gender diversity within the younger generation's media engagement. These changes to the Iranian American population over time and how it is studied are also compounded by the changes in the "host" society.

That is to say, the second generation has entered adulthood in a very different America than that into which their parents immigrated decades ago. Bozorgmehr's most recent documentation of post-9/11 consequences for Iranians in LA, and for Middle Easterners in the USA in general, has contributed to understanding and conceptualizing the negative changes over time that this immigrant population has collectively endured. But we also know that the Iranian second generation is doing relatively well in positioning themselves in American society in many regards. Maghbouleh's work on second generation Iranian Americans makes an argument for Iranian-ness as "an affirmative identity" (Maghbouleh 2012) that empowers young people to make collective bonds, as well as take critical stances toward the "host" society. And Bozorgmehr and Douglas' contribution points to an upward socio-economic trajectory for second-generation Iranian Americans (Bozorgmehr and Douglas 2011) in contrast to the thesis of "second-generation decline" (Gans 1992). Hence, the Iranian American second generation is developing its media uses within a host context that has changed much in one generation, and is a group that occupies an ambiguous positioning within that context.

In addition, changes in diasporic media production are underway as internet-based media are increasingly produced outside the exile media hub of LA. Other cities with large Iranian populations are home to Persian language web radio stations like Radio Javan and Biya2.com 
in DC, and Iranican.com in Toronto. ${ }^{12}$ As successive generations come of age and sites like these and others proliferate, LA's older exile community and its prevalence within the Iranian diasporic media sphere may well wane. Whether this signals a move toward new cultural industry centers and new modes of Iranian diaspora media production remains to be seen, as LA remains an influential reference point for Iranian American-ness globally, and as Maghbouleh notes, the LA Iranian culture industry also has gained influence inside Iran (Maghbouleh 2012). But the dominance of LA in the future diasporic media landscape is increasingly uncertain with the rise of new generations and media forms. And this signals a clear need for research that sheds light on precisely what kinds of changes are taking place, and which alternative analytical frames might best help to understand these socio-cultural and mediatechnological dynamics together. I use my focus on the city of LA as a way to deepen and delineate the situated understanding that my investigation offers.

\section{The Place: Los Angeles as a Global Hub for Media AND Migration}

The city of LA is not just a neutral backdrop to this story. It places my respondents' lives within an urban environment with concrete implications for cultural transmission, media production, and modes of sociality. For instance, the distinct presence of Iranian Americans in many neighborhoods in and around LA County has strengthened the second generation's identification as "Iranian" due to them being surrounded by other Iranians, with ease of language transmission and retention as one of the results of this (Mahdi 1998). But like all cities, LA is not a homogenous place with singular effects on its population. Its development and infrastructural growth have shaped and been shaped by how various migrant populations have inhabited the city, especially according to class and ethnic distinctions. The early development of LA's Westside reflected economic competition with Downtown LA, resulting in today's LA landscape being rather two-headed. Both centers are steeped in affluence and reflect what has been argued is an approach to urban planning and architecture that excludes the poor and working classes (Davis 1992). The experience of living in and moving through the different spaces of the city can make this very clear at times. 
Furthermore, the Westside emerged in the 1920s as a (European) Jewish center as a result of the film industry's (mainly Protestant) exclusion of this group despite their wealth (Davis 1992). This part of the city then experienced an influx of Jewish immigrants during the Second World War, which was combined with a new middle- and upper-class local populace (Fine 2004). It was mostly within the affluent Westside that my research activities were concentrated, but spanned from Orange County to the Valley with stops between. The Westside was the area of LA to which Iranian Jews gravitated upon their arrival, but experienced some difficulties because of the predominantly Ashkenazi background of the Westside Jews (Jalali 2005). The Westside-especially Westwood and Beverly Hills-are, nevertheless, largely settled today by the Jewish Iranian community, known for their affluence. East LA, by contrast, is known for its large Hispanic populations, and a relatively less wealthy and working-class demographic. As Fine writes:

Multiethnic from the beginning, but dominated by the Anglo-Protestant downtown plutocracy, Los Angeles in the 1920s was moving towards its present configuration-massive westward spread, Westside affluence, and increasing racial and class segregation along east-west lines. (Fine 2004)

By 1930 East LA constituted the nation's largest Mexican barrio, booming in the early twentieth century with the key period in the city's industrialization (Romo 1983). Iranian American respondents who I met, who work, live, and grew up in this part of the city, spoke about a qualitatively different experience than their West LA counterparts, as did those whose families called South Central or other parts of LA home. This spatialization of the city shapes everyday life for its inhabitants, and the class and racial/ethnic diversity and hierarchies that play into this spatialization also have repercussions for ways of being Iranian Americans in LA.

Much of the work done on Iranians in the USA between the late 1980s and early 1990s was on Iranians in LA, California (Bozorgmehr 1998: 14). Perhaps most significantly this included Kelley and Friedlander's Irangeles: Iranians in Los Angeles (1993), Naficy's Exile Cultures: Iranian Television in Los Angeles (1993), and Waldinger and Bozorgmehr's Ethnic Los Angeles (Bozorgmehr and Waldinger 1996). This work, in turn, contributed to solidifying the presence of Iranians in LA (Feher 1998; Jalali 2005). It is noteworthy that most of this scholarship on Iranians in LA came from researchers and institutions based in LA and California, many 
of whom were Iranian themselves, lending not only a self-contained quality to the city in its relationship to this particular immigrant population but also a merging of scientific and social dynamics around notions of being Iranian that was concentrated in this particular city and the (inter)nationally high academic standing associated with it and the state of California.

In addition, LA is a national and international center for media production. It is home to leading print news outlets and major entertainment production studios. These powerful institutions are also responsible for producing highly contested media representations of migrants and other minorities. LA Iranians find themselves in close proximity to a film industry that shapes their lives through its mass media representations of Iran, Iranian Americans, and Middle Easterners. But it is also the center of where American-ness is shaped by the film industry. Powdermaker's impressive 1950 ethnography of cultural producers in the Hollywood movie industry points out how the films coming out of these studios are themselves a "uniquely influential institution in US society" (Mahon 2000). She points out the nuances of the tensions between economic forces and artistic goals that are governed by the social system in which cultural producers in Hollywood operate. Although the music industry is not mentioned, this is another major part of the global commercial cultural production emanating from LA, and contributes to the power of LA as a center of global media influence through the "dreams it manufactures" (Powdermaker 1951).

From 1950s Hollywood to today's Silicone Valley, California is also a place of media genesis on a global scale when it comes to the ICT industry. Arguably, the dream being manufactured there is that of technologically enabled societal liberation, and the social system that actors operate within is that of the archetypal venture capitalism-fueled tech start-up. ${ }^{13}$ The expansiveness of the tech industry (an important part of the California state economy) means that Iranian Americans and other ethnic minorities end up increasingly becoming a part of the workforce of this industry at different levels. From the heralded CEO of Google and the head of eBay, to the youthful employees who were interviewed at the Facebook headquarters as part of CNN's coverage of the role of Facebook in the 2009 elections, to Sepideh who worked for Google's Santa Monica branch, to tech journalist and author Cyrus who grew up in Santa Monica, Iranian Americans (the second generation included) are among those who not only use internet applications, but are also sometimes involved in their technical development and in (re)producing the discourses around them, 
either in their capacity as professionals in the area of programming and web development, or as journalists who cover these developments. They are implicated as active participants in the ways the internet develops at the technical and discursive levels, and thus play some role in the history of the technological development (Agre 2002; Turner 2010). Their roles are also particular to the condition of living in proximity to media and technology hubs within California.

Finally, the city's infrastructure shapes access to telecommunications. The economic geography of the internet reflects a global tendency toward the concentrated development of internet backbone networks around already-existing telecommunications infrastructure in world cities (Malecki 2009). This supports speculation about the defining role of world cities in the development of global internet connectivity, by such prominent theorists as Emanuel Castells (2000) and Saskia Sassen (1995). However, as Townsend suggests, empirical investigation of these ideas was lacking as much as the lack of empirical investigation of opposite claims, such as Nicholas Negroponte's (1995) ideas that the internet's development would lead to a decentralization rather than a centralization of communications technologies around already-established urban nodes (Townsend 2001).

As technologies spread, empirically grounded work fuels debates over which explanatory models best encompass the changing processes of internet's infrastructural centralization around global cities (versus decentralization via other locales). With regard to the dynamics of inequality within (global) cities themselves, Townsend presents the startling finding that LA's distribution of domain names in comparison to San Francisco's, for instance, are much more unevenly distributed:

[I]mmigrant and minority neighborhoods show little internet activity. Within the San Francisco area, the difference in domain name density between academic Berkeley and poor, ethnic Oakland is hardly on the scale that separates South Central Los Angeles from the affluent Westside. (Townsend 2001) $)^{14}$

I spent my fieldwork period staying in and visiting various parts of what is officially The Greater Los Angeles Area. This area refers to a region that includes five counties, including Los Angeles County, Orange County, San Bernardino County, Riverside County, and Ventura County, the combined populations of which give LA its megacity status. The city's 
population within the Metropolitan Area and the Greater Los Angeles area, make it the second largest in the country after New York, based on a 2005 US Census estimate. Yet it is important to note that the patterns of uneven distribution of internet access and usage across Los Angeles means that the Westside focus of my investigation is by definition partial and skewed by the people and places in the city within which my study was situated.

The Los Angeles Metropolitan Area-where I ended up spending most of my time and where most of my respondents also tended to spend much of their time-contains various parts, some of which are officially "unincorporated" parts of LA City, such as East LA. Generally speaking, the city is divided into: Downtown LA, the Eastside and Northeast LA, South Central, the Harbor Area, Wilshire, Hollywood, the Westside, and the San Fernando Valley Area. I met people and attended events located across most of these areas, with a concentration in the Westside and Wilshire, where most of the gatherings took place and where several of my respondents, lived, worked, and studied.

\section{The People: Who Is This Book About?}

This book is about a number of young people I got to know during a little over a year of living in LA. Living among second-generation Iranian Americans in LA and observing their practices and speaking with them allowed me to follow them through parts of their daily activities, and therefore trace their enacted and discursive connections to other people, places, and things. I conducted ethnographic research that followed several children of Iranian immigrants in LA and the connections they made, spending time with them in various contexts, asking them about how they use digital media and think about their own internet practices and "the internet" more generally. My research practices also included developing friendships, and I came to share an apartment for several months with one friend, and have continued exchanges with others. I noted during fieldwork that despite the fact that most research on second generation migrants defines this group according to place of birth, this was an arbitrary, even meaningless cut-off point to use given the social dynamics and self-identifications among my respondents. Based on this realization (particularly for those who migrated with their families very early on in life), I defined the second generation as the children of those first-generation migrants who migrated as adults. This of course includes those who were the first in their nuclear 
families to be born in the USA, but it also includes those who migrated as minors, together with their parents. Hence, I focused on a carefully selected group of young people whose parents had migrated to the USA, either before or not very long after their birth.

Formally, I spent a total of 13 months doing fieldwork in LA (between 2008 and 2009). I also returned to the field for over a month in 2013 where I presented some of my findings to an audience that included some of my respondents, as well as had informal conversations and shared parts of my writing for comments as part of efforts toward respondent validation. I started the process of accessing and selecting respondents by approaching a wide range of people, and thus my fieldwork included meeting and conducting interviews with both first- and second-generation Iranian Americans living in the city. These yielded roughly 70 conversations varying in length from 20 minutes to 4 hours, which were recorded in a variety of ways, from voice recordings and direct transcription to notes taken during, or impressions noted afterwards.

This material was supplemented by material from my field notes taken at dozens of events as well as based on shorter, informal conversations I had with people there, as well as interactions in people's homes. I also took photographs of some of these events, including photos of media (in the form of print booklets and sign boards). My notes also cover some of the interactions with a few of the young people I befriended more closely and whose family and friends I met and whose lives I became a part of for a longer time than the fieldwork period, two of whom I was already in touch with via my earlier research on Iranian bloggers. Due to my ongoing interactions with my respondents online, it became more difficult each time I returned to the Netherlands to say that I had left the field-an experience I am sure anthropologists of all (sub)areas are increasingly noticing.

When writing up the accounts my respondents shared with me in this book, I most often use people's actual first names, unless people asked me not to reveal their identities or where unavailable to confirm. In these cases I have used pseudonyms. During the writing process, I noticed that when engaging with versions of my work-in-progress, some respondents could recognize themselves and one another despite my use of pseudonyms. Hence, my effort to make use of people's real names is intended as a measure of avoiding a layer of obscurity, not only for readers in general but also for those about whom I am writing and their fellow community members who might know them. ${ }^{15}$ I have omitted their surnames in most cases as I do not see value in identifying them to strangers. 
Nevertheless, I acknowledge that in some cases, links I make to online content can identify people beyond first names. I made judgments and selections about omitting or obscuring such links in certain cases, in particular when sensitive issues were being discussed, and noting that when I used verbatim quotes from online sources, search engine applications make these statements traceable (when made on publicly accessible websites), making the authors more easily identifiable.

Notwithstanding these considerations, more often than not, I have included links to material I refer to online in the service of context, interest, and research transparency. ${ }^{16}$ Hence, in many instances the quotes and descriptions I present can be traced, verified, and reflected upon directly in their original, online form by the reader via the hyperlinks provided, including by those about whom I write. ${ }^{17}$ My hope is that the details I include help to embed the knowledge this investigation produces within the community in question. It is to this same end that I incorporated the comments I received from respondents on the book manuscript into the text.

Although I approached a wide variety of people from the Iranian "community" in LA, including first-generation Iranian Americans, the key intention of this investigation is not to be comparative between generations, but to follow connections between the second generation and other relevant actors. My main respondents ended up being a group of about 20 people I conducted in-depth interviews with, and about ten people who I had repeated contact and closer friendships with and whom I came to rely on as key respondents. I mainly gained initial access through youthoriented organizations for Iranian Americans including student organizations geared toward academic, social, and cultural programming for their members. They also introduced me to one another based on their knowledge of my research interests, putting me into contact with other people and organizations.

The people that drive the story of this book are mostly those members of the second generation who play a unique and active role in contributing to how Iranian American-ness is articulated in LA (whether among their friends and family, fans and followers, or wider publics). This is a task that also most often involves digital media in some important capacity, and they took up this task as educators, artists, intellectuals, students, photographers, poets, organizers, activists, DJs, filmmakers, and other kinds of professionals. Though not all necessarily "community leaders" in any formal sense, I would say that many of them, certainly, are part of a cultural avant garde when it comes to putting 
their own formations of Iranian American-ness into practice, and giving form to Iranian American-ness through these practices.

I realized that rather than having taken the self-identification as "secondgeneration Iranian American" as a basis for defining my sample, I had been interested in people who actively engaged with the notion of Iranian American-ness. And so, the account I present is one focused on these people's practices of rejecting and denying this label, as well as stretching, re-shaping, and re-appropriating to fit and include them. I followed how they use the label critically, productively, and often from its margins. In this regard, my respondents often felt they were not typical Iranians in LA. Levitt and Glick Schiller distinguish ways of "being" from "belonging" transnational(ly); according to this distinction, my respondents are not only "being" Iranian American (through mundane social interactions that place them in connection with both Iran and the USA), but are also claiming "belonging" to a transnational Iranian American social field (which includes making a conscious connection with an identity label, "combining action and awareness") (Levitt and Schiller 2006).

I will explain more about social fields in the following chapter, but I mention it here to clarify that by telling these people's stories I do not want to give the impression that all Iranian Americans of the second generation are as explicitly invested in identity labels and cultural politics as my respondents are. That being said, we should heed Levitt and Glick Schiller's reminder that conscious engagement with migrant identity is not constant, but depends on young migrants' personal development throughout their life cycle, as well as important developments in the "homeland" (Levitt and Waters 2002; Levitt and Glick Schiller 2004; Levitt 2009). Hence, even those who at moments in their lives actively participate in re-negotiating labels at other times seek to disengage from them (with varying success), for instance, preferring to be seen as a musician/writer/scholar rather than an Iranian American musician/writer/ scholar. In other words, the variety of their positioning professionally, publicly, and personally, did not always explicitly involve identity claims to Iranian American-ness, but were also non-explicitly practiced through ways of being Iranian American in living their daily lives.

Despite their self-perception as somewhat marginal players within the community, my respondents' high education levels and predominantly middle-class backgrounds meant that they are well-connected, both with one another and with institutions, organizations, technological infrastructures, and even, at times, with the public debates that implicated them. 
They also came from families and had career prospects where uppermiddle class life would be attainable for them. Hence, while coming from an ethnic/racial minority in American society, as a whole they are among the city's most resourced minorities. And despite perhaps belonging to a minority group of the Iranian American population in LA, they also have the status of a potentially influential minority of a minority. My focus on this particular group necessarily makes this book's analysis a partial one. Yet, its contextualized depth means that the claims I make reveal things about how processes of mediation and migrant identification may work more generally.

Although I made efforts to include a range of people, practices, and voices when conducting fieldwork, I did not select my respondents so as to make up a representative sample of the religious/ethnic variety of the demographic makeup of LA Iranians. This was a result of accessing respondents through an informal web of contacts-of-contacts-a kind of qualitative social network tracing also known as snowball sampling. It is perhaps for this reason that my key respondents turned out not to include the Iranian Americans who explicitly identified as Jewish; rather most of them identified as having a Muslim cultural background or being practicing Muslims. A tiny minority mentioned having been raised Christian, and for others the issue of their religious self-identification did not feature explicitly in the conversations we had. It is also perhaps an indication of the group dynamics among them that the gender composition was split rather evenly between men and women.

My respondents' lives unfolded in a range of settings in the city, from people's houses, to college campuses, to workplaces, to stores, cafes and restaurants, to the cars they drive in between these places, to gatherings of various sizes and kinds, in living rooms, in parks, in cultural centers, libraries, museums and galleries, cinemas, and on street corners. In addition, as part of being in the field I was constantly using media. I visited the websites people told me about, watched the various ethnic media channels available to them in LA, including well-known local radio channels and certain satellite broadcasting, sometimes together with my respondents, as well as being exposed to the myriad of media messages more generally that came with living in LA. This included gathering information from and about websites that my respondents used. I did this by saving textual and visual content, often in the form of screenshots. ${ }^{18}$ Furthermore, my respondents and I got in touch and communicated with one another through email, messaging, and social media applications. 
Through these channels I learned about events in the field, and through web telephony and instant chat, I stayed in contact with some of them after leaving LA or during times they were away. This was not only because my research concerned internet and media but also because these web applications were, and increasingly are becoming, the standard tools of fieldwork. The abundance of various forms of media use as part of fieldwork practices speaks of the ubiquity of media in almost any contemporary ethnographic field site. In large part, I accessed my respondents' web- and wider internet use by engaging with them through it. This included being on Facebook and Twitter, exchanging emails and photos, chatting online, reading one another's blog postings, and so on. It also meant observing as they engaged with others through these applications. For instance, when people showed me photos they shared on social media by handing me their smartphone in a café, or in the rooms of their houses as they showed me web videos or blogs they liked or followed on their desktop computer, or when I was present when they interacted with one another in a group around someone's laptop, or as I sat next to them and they showed me who they were chatting with online.

\section{Posing Research Questions from an Insider- Outsider Position}

During the course of doing this research, I (re-)experienced some of my own ambivalence about being Iranian, as well as my increasingly mixed feelings toward the USA. I recognized some of my research experiences in the reflections of researchers who have written about the problematic fixities implied in the notion of the "native anthropologist" (Narayan 1993). My bilingual upbringing in Australia, my English language education in international institutions in the Netherlands, and my recognition of Western cultural reference points through consumption of English language media immediately made me a convincing American to most of those I met in LA. However, my outsider status was revealed in my story of being a resident of the Netherlands, having grown up in Sydney, Australia, never before having lived in the USA, and not identifying as American. I told people I met in the course of my research my own story as thoroughly as possible. And I think this particular positioning made it easier for me to look at American-ness from a critical distance without, at the same time, being a complete stranger to it. 
My experience as a child of Iranian parents and living in a transnationally dispersed family since childhood also made my field experiences familiar to me in intimate ways. Growing up in Australia my mother would laugh while tenderly satirizing my (now late) paternal grandmother who lived in Tehran. My parents would talk about her memorably comical way of using the telephone in the family house, the house they shared with her and the rest of my father's family for the first years of their marriage before I was born. When people would call from overseas, her voice would rise from the moderate "alo?" ("hello?") with which she answered the phone, to a vociferous shout at the moment of realizing who the caller was and the distant location from which the call was reaching her. The volume of conversation would rise a little even when friends and family would call from Shiraz several hundred kilometers away, my mother described. But never as much as for an international call: a call from khaarej (overseas-literally "outside"). A little over a year after my birth, my parents re-located our small family to Sydney, where we were the ones on the other end of those international calls now. And my dear grandmother's shouting voice came to us across the ocean and over the wires we relied on and devices we spoke into.

It was not only with my grandmother with whom I was raised to speak over the various phones that sat in each of the living rooms we moved into over time in Sydney. I grew up knowing a range of relatives in Iran only through those phone conversations and the few precious photo albums my parents brought with them when they fled Iran during the war. Then there were the letters that came for my parents in Farsi, the script that was consistently and familiarly indecipherable to me for my entire childhood and yet which I remember so clearly as the writing of letters from afar and my mother's diary, a small book she had brought with her from Iran-the albums, those letters, and of course that all-important telephone. That was what we had of those people and that place.

And so my parents would encourage me to speak to these relatives over the phone as a child. Sometimes gingerly and sweetly enticing me with stories of how deeply those strangers had loved me as a small baby, sometimes coercing me with social obligation and cultural custom. And so I spoke and listened, sometimes with love, other times robotically. And later I wondered if I would one day laugh with my own (unborn) children at my parents' practices with the phone, the same way they had laughed about my grandmother. I also wondered what it would mean for transnational families like mine that a host of new communications technologies were 
mushrooming in use across the globe. Technologies that most of my family members would never have envisioned becoming a part of our regular ways of being in touch with one another, but which I learned during my fieldwork were modes of communication some young people relied on to keep in touch with family in Iran. Indeed, during the fieldwork for this book, I attended a theater production put on by one of the Iranian student groups I had contact with. The play included a humorous skit in which the character of the Iranian grandmother in LA who was the lovable butt of a joke about how she used the internet telephony program, Skype, to make international calls to Iran, including that familiar idiosyncrasy: shouting.

It was interesting to see this trope played out in front of a full theater of people who likely got the joke on the same intimate level I did. It also raised questions about how these kinds of reference points to the minutiae of mediated transnational life might be shared to create a sense of community within pockets of Iranian America. How might other such cultural points of reference be shared? And how might these references, themselves, be mediated? For instance, through a theater play, blog posting, or podcast that connects them with their peers in LA or other places where the Iranian diaspora takes shape. How are these young people implicated in processes of cultural formation and transformation that place them at once amidst social surroundings in LA and transnational relationships with people and places far away? And how do these cultural transformations develop hand-in-hand with the technological developments apparent in everyday life? As I have discussed in this chapter so far, to try to address these issues I conducted ethnographic fieldwork that delved into the lives of my respondents as they traversed online and offline settings. In what follows, I outline how I approached the challenge of how I delineated my field site in a world of seemingly endless interconnections.

\section{The Field: Delineating the Parameters and Practice of Online-Offline Research}

The notion of "field" is central to how I delimit this study and define my research practice. In the 1990s, dynamic conceptualizations of culture saw anthropologists increasingly calling for methodological approaches that treat the cultural object of study as complex and fluid, rather than a static entity bound to a local site. This led to the persuasive proposal of "multi-sited fieldwork" (Marcus 1995), and discussion of the challenges of studying cultural "flows" and movement (Appadurai 1996). Since then, 
the notion of field continues to be re-theorized in efforts toward a view of cultural practices that encompass people's modes of living in a mediated world (Bird 2013). ${ }^{19}$

Amidst the recent rise in social scientific attention for digital and internet technologies, anthropologists have made many efforts to position their discipline as one with already-existing methodological principles and tools that can fruitfully be applied to new digital objects of study (see Horst and Miller 2012). Yet as anthropologists engage in research on swiftly developing digital technologies and increasingly differentiated software applications, notions of ethnographic practice and concepts of the field require consideration anew. As John Postill and Sarah Pink state:

For the internet ethnographer, the implications of the shift to web 2.0 and the rapid growth of social media platforms, applications, practices and activity are threefold. They create new sites for ethnographic fieldwork, foster new types of ethnographic practice, and invite critical perspectives on the theoretical frames that dominate internet studies, thus providing opportunities for re-thinking internet research methodologically. (Postill and Pink 2012: 124)

Regarding the emergence of new sites for fieldwork that call for new research practice, Coleman discusses socio-technical phenomena that rely solely on the existence of digital communication (Coleman 2010). And Boellstorff argues that the sociality of online worlds must be studied in its own right without the researcher seeking to methodologically merge it with or analytically reduce it to offline social worlds (2012). This calls for a theory of field that encompasses the complexity of online-offline practices that make up people's everyday lives. It has also led to a thriving area of work concerned with innovations in ethnographic methods in the context of digital media's rise (Hine 2015; Pink et al. 2015). Postill emphasizes the need for moving beyond abstract conceptualizations of the impacts of internet technologies, and thus also beyond the dominant yet under-determined concepts of "network" and "community" to the internet, which tend to generate broad explanations of this technology's supposed impact upon society. Postill theorizes "field" as an alternative to the ascendancy of these two concepts, basing this theorization on detailed analysis of social and political processes and their digital dimensions, and calling for scholarly attention for the multiplicity of social forms beyond networks and communities produced by careful empirical investigation $(2012) .^{20}$ 
Field is a useful notion for approaching digital media via its local incarnations, accessing this through specific users in the contexts of their daily lives. Such a notion of field applied to Iranian diasporic identity formation in this case includes the significant forces and actors that surround the second generation. The field of second-generation cultural identity formation is produced through how my respondents relate and respond to ( 1 ) their parents and influential older members of "the Iranian American community," (2) their counterparts back in Iran, (3) Americans in the USA-including a range of other "minority" groups, and (4) other parts of the Iranian second generation in LA and other places in the world. These groups and actors exert influences on the young people this book is about, shaping how they (think they should) live their lives. And it is by following these ongoing negotiations online and offline that I define my field. Finally, a notion of field produced through its participants' practices encompasses the existence of multiple (sometimes) connected local contexts. And in the theories of/inspired by Pierre Bourdieu, field is also defined by the set of social forces beyond the local, which structure processes within it. Hence, the outcomes of this situated study of the ongoing, parallel processes of cultural and technological change over time in a particular locale feed into a larger body of research contributing to answering questions of how human societies (and cultural identification processes, in particular) are changing with the rise of digital media.

\section{The Structure of This Book}

In this chapter, I have outlined the main question driving this research and described how it arose from a need to update research on Iranian diaspora by documenting and analyzing how culture is lived dynamically via new technologies. I have also outlined the methodological principles and choices that define how I will answer this central question. In other words, this investigation is situated by the ethnographic fieldwork I conducted on my respondents' media usage. By doing this I traced how "Iranian American" is defined and negotiated situationally, being co-constituted by a range of cross-cutting facets of my respondents' selves. This is as much an investigation of internet technologies as it is of second-generation Iranian American-ness, and I outline how I conceptualize "the internet" in Chap. 2, when I also discuss the theories of migration and media that inspire the ideas put forward in this book. 
Chapter 2 deals with the conceptual debates within the multidisciplinary fields of migration research and media theory. The chapter relates the dynamics that took shape within my field site to more than the local developments and the Iranian diaspora. It is where I sketch the positioning of my research with relation to migration studies research, and the area of second-generation studies in particular. I bring the work on changing migrant demographics and identities together with media anthropological approaches for understanding digitally mediated identity formation processes, making a case for the value of transnational frames for studying diaspora online and offline. Nevertheless, each of the three ethnographic-based chapters that follow this one includes a brief overview of debates that pertain specifically to the topic of the respective chapter, and can therefore also be read independently of the theory chapter.

Chapter 3 is the first of the three empirically driven chapters, and foregrounds notions of the past, heritage, and remembering. There I focus on the relationships my respondents have to the past. I discuss how history and heritage are engaged with through (digital) objects and stories that refer to Iranian and American pasts, asking: how do my respondents position themselves with relation to a past that they see as pertaining to them, as their own, and how is this past mediated in ways that speak to these young people? I argue that the ways these connections take shape relies on the styles of remembering that appeal to the second generation, and that they position themselves with the help of their internet usage that helps them contest, reframe, and engage critically with the past through the lens of their contemporary experiences of growing up in the USA. Their practices also show how the past is mediated through particular narratives and objects alike, such that the materiality of certain things and pre-existing institutions for remembering and heritage maintain their power.

Chapter 4 focuses on race. In it, I investigate how my respondents engage with ways of seeing the body and ways of seeing (and being seen as) Iranian Americans as a group (through various forms of political and media representation). I focus on the question of how my respondents represent their racialized bodies and narrate their experiences of racism through their uses of web applications. How do they use the internet to position themselves by mediating their experiences of racialization? I argue that certain styles of presenting the racialized body with the use of internet media are particular to the second generation and mobilize emergent forms of collectivity, showing how these draw on and disjoin from the previous generation's modes of positioning within a changing 
context of racial discrimination. In a similar way to notions of home and the past, the issue of race constitutes Iranian American-ness for my respondents, but through a positioning that is only beginning to be discussed in research on Iranian diaspora.

Chapter 5 focuses on the Green uprising in Iran that took place during my fieldwork period in LA. The chapter starts out by acknowledging the dominant narratives about "social media" circulating around this period, and moves on to focus upon my respondents' practices and narratives during the same period. It shows how the events in Iran represented a moment in which Iranians in the diaspora came to practice their Iranian-ness transnationally, and how my second-generation respondents in particular came to see themselves as connected to Iran and Iranianness in ways specific to this moment. It also discusses the role of particular web applications and their use, showing how they offer certain possibilities and how these possibilities are also limited in various ways. Hence, in each of the chapters, the issue of my respondents' cultural belonging is approached from a different vantage point. Each chapter aims to elaborate upon a particular facet of Iranian American belonging I observed as important in the field and examine how the use of internet helps mediate that belonging. In closing, Chap. 6 summarizes the main conclusions from each chapter as they relate to the concept of secondgeneration "digital styles" and suggests this concept as a possible way in which to understand the processes through which second-generation migrant identities are mediated digitally.

\section{Notes}

1. The site has since become inactive. The last Twitter updates are from posts in 2010 .

2. She writes this in her blog description.

3. Also referred to by some as "Blogistan" (Hendelman-Baavur 2007; Sreberny and Khiabany 2010).

4. I further discuss the literature on these Farsi language blogs in Chap. 5.

5. This was due to the language barrier in proficiency.

6. An additional intermediate wave has also been defined between 1970 and 1978, comprised of an affluent, urban populace who had become wealthy during these years of economic growth. Like the 
first wave, their motivations for movement were also largely economic and professional, and they were dispersed throughout the country (Jalali 2005).

7. Zohreh Sullivan's work on Iranian exiled intellectuals in LA shows the productivity of diaspora within a literary studies tradition. That is, she sees exile as having more diverse, metaphorical meanings for migrant imaginaries than only loss and longing (Sullivan 2001). Ghorashi similarly foregrounds the productive possibilities of the liminal condition of hybridity, but she also argues for making a conceptual distinction between exile and diaspora. The former helps harbor sentiments of a lost national homeland, while the latter helps embrace new beginnings (Ghorashi 2002, 2005). Sreberny-Mohammadi makes a similar distinction, drawing on Brah's discussion of diasporic space, which leads her to understand Iranian diaspora as a "looking around" in an "all-around" and "multi-directional" gaze, in contrast with the inward looking of a focus on ethnicity and a backward looking of exile (Sreberny 2000).

8. The exile character of Iranian migration that has long defined it has invoked interesting comparisons with pre-/post-revolutionary Cuban immigrants/exiles (Bozorgmehr 1986: 3) and Palestinian immigrant experiences in the USA (McCloud 2006: 103).

9. Though the notion of a "transnational generation" may offer an analytical encompassment of the lives of young Iranians in Iran and how it is shaped by diaspora influences, that investigation lies outside the scope of this research.

10. Although this atmosphere is not without its changes and shifts with the changing of Presidents and (informal) policies.

11. The study of Iranian Americans is an area to which he and collaborators contributed a considerable amount of scholarship in the 1980s and 1990s (Sabagh and Bozorgmehr 1987; Bozorgmehr and Sabagh 1988; Bozorgmehr and Waldinger 1996; Bozorgmehr 1997; Bozorgmehr and Sabagh 1998; Bakalian and Bozorgmehr 2009). This includes a particular focus on LA in some early work. The bulk of this is based on predominantly quantitative data and analysis.

12. Radiojavan.com; Iranican.com; Iranian.com; Biya2.com.

13. Scholars from various disciplines have pointed to the ways in which the beginnings and developments of networked digital technolo- 
gies in California have become entwined with notions of communitarianism and an idealized vision of "community," millennialism, pioneering in a new world, and the fundamental transformation of society mixed in with elements of the transcendental, but also how this has undergone change and continuity over time (Agre 2002; Turner 2010; Zandbergen 2011).

14. Townsend has also argued vigorously that the dependency between cities (rather than competition) that comes with interconnected networks of communications technologies are shaping relationships and hierarchies between cities in more complex ways than a global cities thesis allows (Townsend 200la, b).

15. I became aware during my fieldwork that many of those I spoke to were, themselves, either conducting academic research having to do with Iranian diaspora or related issues, or held an active stake in the public representation of Iranian American-ness. Hence, I feel obliged to make my account of affairs recognizable and accessible to this audience.

16. I did not see any basis for inferring that this research practice would cause any increased risk to the respondent. This was my basis for deciding if an issue was sensitive or not. I acknowledge that the effort to minimize risk is not the same as eliminating risk, and operate with the knowledge that despite these efforts there are no perfect ethical solutions in doing research and I am open to being held accountable by my respondents regarding how I represent them in the account I present in this book.

17. My choice is based on the assumption that in the eyes of at least some of my respondents, being certain about when I am writing about them and others whom they might know, lends a degree of transparency to my account. They may, thus, be in a better position to judge the credibility of the account. In general, I followed the basic ethical principles of minimizing risk as much as possible to my individual respondents, and maximizing my own accountability by being as transparent as possible about my own research process and sources.

18. Both screenshots and copy-pasted material from websites were copied into word processing document formats and later imported to the qualitative data analysis program I was using to organize and code the rest of my interview and observational material. Newer versions of such programs have the functionality of directly down- 
loading material from websites and code segments of images (e.g. Nvivo 10). This was more difficult to do in the version of the program that I was using. Hence, screenshots were coded as whole images, and closer analysis of their content was done without the functionality of the program. Videos were generally not downloaded into the database, but the links to particular videos were saved.

19. This is a perspective that highlights the anthropological principle of holism. However, see Hine's work for a critique of holism in the endeavor of "virtual ethnography" and an embrace of partiality (Hine 2000). See Horst and Miller for a revitalization of digital anthropology's commitment to holism (2015).

20. He argues for field as something produced empirically in context, in the form of "the field of residential affairs" in a Malaysian town whose residents use internet platforms to engage as political agents.

\section{BIBLIOGRAPHY}

Agre, P. E. (2002). Cyberspace as American culture. Science as Culture, 11, 171-189. doi:10.1080/09505430220137234.

Alinejad, D. (2011). Mapping homelands through virtual spaces: Transnational embodiment and Iranian diaspora bloggers. Global Networks, 11, 43-62.

Amir-Ebrahimi, M. (2004). Performance in everyday life and the rediscovery of the "Self" in Iranian weblogs. Bad Jens: Iranian Feminist Newsletter, 7, $23-31$.

Aouragh, M. (2011). Confined offline, traversing online Palestinian mobility through the prism of the internet, mobilities. Mobilities, 6, 375-397.

Appadurai, A. (1996). Modernity at large: Cultural dimensions of globalization. Minneapolis: University of Minnesota Press.

Balkalian, A., \& Bozorgmehr, M. (2009). Backlash 9/11: Middle Eastern and Muslim Americans respond. Berkeley and Los Angeles: University of California Press.

Bird, E. (2013). From fan practice to mediated moments: The value of practice theory in the understanding of media audiences. In B. Bräuchler \& J. Postill (Eds.), Theorising media and practice (p. 352). New York: Berghahn Books.

Boellstorff, T. (2012). Rethinking digital anthropology. In H. Horst \& D. Miller (Eds.), Digital anthropology. New York and London: Berg Publishers.

Bozorgmehr, M. (1997). Internal ethnicity: Iranians in Los Angeles. Sociological Perspectives, 40, 387-408.

Bozorgmehr, M. (1998). From Iranian studies to studies of Iranians in the United States. Iranian Studies, 31, 5-30. 
Bozorgmehr, M., \& Sabagh, G. (1988). Survey research among middle eastern immigrant groups in the United States: Iranians in Los Angeles. Middle East Studies Association Bulletin, 23, 23-34.

Bozorgmehr, M., \& Sabagh, G. (1998). Emergent ethnicity: Iranians in Los Angeles. ISSR Quarterly, 3, 7-10 (coauthor with G. Sabagh and I. Light).

Bozorgmehr, M., \& Douglas, D. (2011). Success(ion): Second-Generation Iranian Americans. Iranian Studies, 44, 3-24. doi:10.1080/00210862.2011.5 24047.

Bozorgmehr, M., \& Waldinger, R. (1996). Ethnic Los Angeles. New York: Sage Publications.

Castells, M. (2000). The rise of the network society. The information age: Economy, society and culture. Malden, MA: Blackwell Publishing.

Coleman, E. G. (2010). Ethnographic approaches to digital media. Annual Review of Anthropology, 39, 487-505. doi:10.1146/annurev.anthro.012809.104945.

Davis, M. (1992). City of Quartz: Excavating the future in Los Angeles. London: Verso.

Doostdar, A. (2004). "The vulgar spirit of blogging": On language, culture, and power in persian weblogestan. American Anthropologist, 106, 651-662. doi:10.1525/aa.2004.106.4.651.

Feher, S. (1998). From the rivers of Babylon to the valleys of Los Angeles: The exodus and adaptation of Iranian Jews. In S. Warner \& J. Wittner (Eds.), Gatherings in diaspora: Religious communities and the new immigration (p. 409). Philadelphia, PA: Temple University Press.

Fine, D. M. (2004). Imagining Los Angeles: A city in fiction. Reno: University of Nevada Press.

Gans, H. J. (1992). Second-generation decline: Scenarios for the economic and ethnic futures of the post-1965 American immigrants. Ethnic and Racial Studies, 15, 173-192. doi:10.1080/01419870.1992.9993740.

Ghorashi, H. (2002). Ways to survive, battles to win: Iranian women exiles in the Netherlands and United States. New York: Nova Publishers.

Ghorashi, H. (2005). Agents of change or passive victims: The impact of welfare states (the Case of the Netherlands) on refugees. Journal of Refugee Studies, 18, 181-198. doi:10.1093/refuge/fei020.

Ghorashi, H., \& Boersma, K. (2009). The "Iranian Diaspora" and the new media: From political action to humanitarian help. Development and Change, 40, 667-691. doi:10.1111/j.1467-7660.2009.01567.x.

Glick Schiller, N., \& Fouron, G. E. (2001). Georges woke up laughing: Longdistance nationalism and the search for home (American Encounters/Global Interactions). Durham, NC: Duke University Press Books.

Hendelman-Baavur, L. (2007). Promises and perils of weblogistan: Online personal journals and the Islamic Republic of Iran. The Middle East Review of International Affairs, 11, 77-93. Article 6/8. 
Hine, C. (2000). Virtual ethnography. London: Sage Publications.

Hine, C. (2015). Ethnography for the Internet: Embedded, embodied and everyday. London and New York: Bloomsbury Academic.

Horst, H. A., \& Miller, D. (Eds). (2012). Digital anthropology (English ed.). London and New York: Berg.

Jalali, B. (2005). Iranian families. In M. McGoldrick, N. Garcia-Preto, \& J. Giordano (Eds.), Ethnicity and family therapy (3rd ed.). New York: Guilford Press.

Kelley, R., et al. (1993). Irangeles: Iranians in Los Angeles. Berkeley and Los Angeles: University of California Press.

Levitt, P. (2009). Roots and routes: Understanding the lives of the second generation transnationally. Journal of Ethnic and Migration Studies, 35, 1225-1242.

Levitt, P., \& Schiller, N. G. (2004). Concentualizing simultaneity: A transnational social fields perspective on society. International Migration Review, 38, 595-629.

Levitt, P., \& Schiller, N. G. (2006). Conceptualizing simultaneity: A transnational social field perspective on society. International Migration Review, 38, 1002-1039. doi:10.1111/j.1747-7379.2004.tb00227.x.

Levitt, P., \& Waters, M. (2002). Introduction in the changing face of home: The transnational lives of the second generation. New York: Russel Sage Foundation.

MacCloud, A. B. (2006). Transnational Muslims in American society. Gainsville: University Press of Florida. http://books.google.nl/books/about/ Transnational_Muslims_in_American_societ.html?id=PSR0QgAACAAJ\&p gis $=1$.

Maghbouleh, N. (2010). "Inherited nostalgia" among second-generation Iranian Americans: A case study at a Southern California University. Journal of Intercultural Studies, 31, 199-218. doi:10.1080/07256861003606382.

Maghbouleh, N. (2012). Iranian American youth and the limits of assimilation. Doctoral Dissertation, University of California, Santa Barbara.

Mahdi, A. A. (1998). Ethnic identity among second-generation Iranians in the United States. Iranian Studies, 31,77-95. doi:10.1080/00210869808701897.

Mahon, M. (2000). The visible evidence of cultural producers. Annual Review of Anthropology, 29, 467-492.

Malecki, E. J. (2009). The economic geography of the Internet's infrastructure. Economic Geography, 78, 399-424. doi:10.1111/j.1944-8287.2002. tb00193.x.

Malek, A. (2006). Memoir as Iranian exile cultural production: A case study of Marjane Satrapi's persepolis series. Iranian Studies, 39, 353-380. doi:10.1080/00210860600808201.

Marcus, G. E. (1995). Ethnography in/of the World system: The emergence of multi-sited ethnography. Annual Review of Anthropology, 24, 95-117. doi:10.1146/annurev.an.24.100195.000523. 
Mason, V. (2007). Children of the "Idea of Palestine" 1: Negotiating Identity, Belonging and Home in the Palestinian Diaspora. Journal of Intercultural Studies, 28, 271-285. doi:10.1080/07256860701429709.

McAuliffe, C. (2007). A home far away? Religious identity and transnational relations in the iranian diaspora. Global Networks, 7, 307-327.

Mobasher, M. (2006). Cultural trauma and ethnic identity formation among Iranian immigrants in the United States. The American Behavioral Scientist, 50, 100-117. doi:10.1177/0002764206289656.

Modarres, A. (1998). Settlement patterns of Iranians in the United States. Iranian Studies, 31, 31-49. doi:10.1080/00210869808701894.

Naficy, H. (1993). The making of exile cultures: Iranian television in Los Angeles. Minneapolis: University of Minnesota Press.

Narayan, K. (1993). How native is a "Native" anthropologist? American Anthropologist, 95, 671-686. doi:10.1525/aa.1993.95.3.02a00070.

Negroponte, N. (1995). Being digital. New York: Vintage Books.

Pink, S., Horst, H., Postill, J., et al. (2015). Digital ethnography: Principles and practice. Los Angeles, CA: SAGE Publications.

Postill, J. (2012). Digital politics and political engagement. In H. Horst \& D. Miller (Eds.), Digital anthropology. London: Berg.

Postill, J., \& Pink, S. (2012). Social media ethnography: The digital researcher in a messy web. Media International Australia, 123-134.

Powdermaker, H. (1951). Hollywood: The dream factory. London: Secker and Warburg.

Romo, R. (1983). East Los Angeles: History of a barrio. Austin: University of Texas Press.

Sabagh, G., \& Bozorgmehr, M. (1987). Are the characteristics of exiles different from immigrants? The case of Iranians in Los Angeles. Sociology and Social Research, 71(2), 77-84. http://www.popline.org/node/346425.

Sassen, S. (1995). On concentration and centrality in the global city. In P. L. Knox \& P. J. Taylor (Eds.), World cities in a world-system (p. 335). Cambridge: Cambridge University Press.

Shakhsari, S. (2011). Weblogistan goes to war: Representational practices, gendered soldiers and neoliberal entrepreneurship in diaspora. Feminist Review, 99, 6-24. doi:10.1057/fr.2011.35.

Sreberny, A. (2000). Media and diasporic consciousness: An exploration among Iranians in London. In S. Cottle (Ed.), Ethnic minorities es the media: Changing cultural boundaries (p. 251). London: McGraw-Hill International.

Sreberny, A. (2001). The role of media in diasporic practices of cultural communities. In T. Bennett (Ed.), Differing diversities: Transversal study on the theme of cultural policy and cultural diversity. Strasbourgh Cedex: Council of Europe.

Sreberny, A., \& Khiabany, G. (2010). Blogistan: The Internet and politics in Iran. London: I.B. Tauris. 
Sullivan, Z. (2001). Exiled memories: Stories of Iranian diaspora. Philadelphia, PA: Temple University Press.

Townsend, A. M. (2001a). Network cities and the global structure of the internet. American Behavioral Scientist, 44(10), 1697-1716. doi:10.1177/ 00027640121957998.

Townsend, A. M. (2001b). The Internet and the rise of the new network cities, 1969-1999. Environment and Planning B: Planning and Design, 28, 39-58. doi:10.1068/b2688.

Turner, F. (2010). From counterculture to cyberculture: Stewart Brand, the whole earth network, and the rise of digital utopianism. Chicago: University of Chicago Press.

Zandbergen, D. (2011). New edge. Technology and spirituality in the San Francisco Bay Area. Doctoral dissertation. 